\title{
FORMULASI SUSPENSI PELET Trichoderma spp. DALAM MENGHAMBAT CENDAWAN Synchitrium pogostemonis PENYEBAB PENYAKIT BUDOK PADA BIBIT NILAM
}

\author{
(Pellet Suspension Formulation of Trichoderma spp. In Inhibiting Synchitrium \\ pogostemon Fungus as the Cause of Budok in Patchouli Seeds) \\ Marhamah Marhamah ${ }^{1}$, Rina Sriwati ${ }^{1}$, Alfizar Alfizar ${ }^{1 *}$ \\ ${ }^{1}$ Program Studi Proteksi Tanaman, Fakultas Pertanian, Universitas Syiah Kuala \\ *Corresponding author: rinasriwati@unsyiah.ac.id
}

\begin{abstract}
Abstrak. Tanaman nilam (Pogostemon cablin Benth) merupakan tanaman penghasil minyak atsiri yang dijadikan sebagai sumber pendapatan bagi banyak petani di Indonesia. Ketelitian dalam memilih bibit adalah salah satu faktor utama penting dalam persiapan penanaman nilam. Di beberapa sentra pengembangan nilam saat ini penyakit budok merupakan masalah serius yang selalu ditemukan. Trichoderma spp. dapat dimanfaatkan sebagai agensia hayati dan memberikan pengaruh positif dalam mengendalikan penyakit tanaman, karena cara ini lebih unggul dibanding pengendalian berbasis fungisida. Penelitian ini bertujuan untuk mengetahui kemampuan formulasi suspensi pelet Trichoderma spp. dalam menghambat cendawan Synchitrium pogostemonis penyebab penyakit budok pada bibit nilam. Penelitian ini menggunakan Rancangan Acak Lengkap (RAL) non faktorial dengan 6 perlakuan terdiri dari 3 unit percobaan dan 4 kali ulangan sehingga diperoleh 72 unit percobaan. Pelet Trichoderma spp. diaplikasikan dengan cara disemprot dengan dosis 2,5 gr/100ml. Hasil penelitian menunjukkan bahwa formulasi pelet Trichoderma spp. mampu menghambat cendawan Synchitrium pogostemonis penyebab penyakit budok pada bibit nilam. Formulasi suspensi pelet Trichoderma harzianum mampu meningkat pertumbuhan tanaman nilam terhadap parameter tinggi tanaman, jumlah daun, dan jumlah tunas pada 42 HST.
\end{abstract}

Kata Kunci: Trichoderma, Nilam, Budok.

\begin{abstract}
Patchouli plant (Pogostemon cablin Benth) is an essential oil-producing plant which is used as a source of income for many farmers in Indonesia. The accuracy in selecting seeds is one of the main important factors to prepare patchouli planting. In several patchouli development centers, a serious problem that is regularly found is budok disease. Trichoderma spp. can be used as a biological agent and has a positive effect in controlling plant diseases, because the method is more superior to fungicide-based control. This study aims to determine the ability of Trichoderma spp. pellet suspension formulation in inhibiting Pogostemonis synchitrium fungus which causes Budok disease in patchouli seeds. This study used a non-factorial Completely Randomized Design (CRD) with 6 treatments consisting of 3 experimental units and repeated 4 times in order to obtain 72 experimental units. Trichoderma spp. pellets were applied by spraying it a dose of $2.5 \mathrm{gr} /$ $100 \mathrm{ml}$. The results showed that the formulation of Trichoderma spp. is able to inhibit the Synchitrium pogostemonis fungus that cause budok disease on patchouli seedlings. The formulation of Trichoderma harzianum pellet suspension was able to increase the growth of patchouli on the parameters on plant height, number of leaves, and the number of shoots at 42 DAS.
\end{abstract}

Keywords: Trichoderma, Patchouli, Budok.

\section{PENDAHULUAN}

Tanaman nilam (Pogostemon cablin Benth) merupakan tanaman penghasil minyak atsiri yang dijadikan sebagai sumber pendapatan bagi banyak petani di Indonesia. Tanaman ini pertama kali dikenal dan ditanam dengan skala besar hampir di seluruh wilayah Aceh sehingga nilam ini terkenal dengan sebutan nilam Aceh. Jenis nilam ini merupakan standar jenis nilam yang diekspor dan direkomendasikan. Hal ini karena nilam Aceh memiliki aroma yang khas dan rendemen minyak yang didapat dari daunya cukup tinggi dibanding jenis lainnya, yaitu sekitar 2,5 hingga 5 persen dan selalu dibutuhkan secara berkesinambungan 
dalam industri parfum, sabun, farmasi, flavoiring agent dan yang lain sebagainya (Panjaitan dan Nuraeni, 2014).

Ketelitian dalam memilih bibit adalah salah satu faktor utama penting dalam persiapan penanaman nilam. Tahap pembibitan nilam, dalam penyiapan media tanah perlu diperhatikan. Tanah bekas penanaman nilam sebaiknya tidak diambil, guna menjamin media bebas dari penyakit tanaman.

Berdasarkan permasalahan yang dihadapi dalam pengembangan budidaya nilam saat ini selama fase pertumbuhannya tidak terlepas dari gangguan Organisme Pengganggu Tanaman (OPT). Salah satu penyakit penting yang menginfeksi tanaman nilam adalah penyakit budok. Penyebab penyakit budok adalah Synchitrium pogostemonis yang bersifat parasit obligat. Cendawan $S$. pogostemonis merupakan cendawan tular tanah yang dapat menyerang daun, tangkai daun dan batang tanaman nilam terutama pucuk tanaman yang baru tumbuh (Yuliyanti et al., 2017).

Konsep pengendalian yang sering digunakan oleh petani yaitu dengan menggunakan fungisida dikhawatirkan dapat menimbulkan berbagai permasalahan dan mengganggu keseimbangan lingkungan, bahkan mendukung perkembangan patogen lebih tahan dan virulen. Saran pengendalian yang dianjurkan adalah dengan melakukan pengendalian ramah lingkungan, seperti pemanfaatan agensia hayati. Trichoderma spp. dapat dimanfaatkan sebagai agensia hayati dan memberikan pengaruh positif dalam mengendalikan penyakit tanaman, karena cara ini lebih unggul dibanding pengendalian berbasis fungisida (Sukamto et al., 2019).

Dilapang dalam aplikasi Trichoderma spp. sering mengalami kendala serta kurang praktis karena membutuhkan banyak wadah bila dalam bentuk substrat juga membutuhkan banyak tenaga kerja. Oleh sebab itu, dicari rumusan tentang Trichoderma spp. yang lebih praktis, efektif, dan efisien (Soekarno et al., 2014). Formulasi merupakan bahan yang dimanfaatkan agen hayati supaya bisa meningkatkan efektifitas kinerja agen hayati serta mempunyai tujuan untuk memudahkan aplikasi dan distribusi (Suswanto, 2014). Berdasarkan uraian diatas, maka perlu dilakukan penelitian lebih lanjut salah satunya dengan menggunakan agensia hayati Trichoderma spp. yaitu memiliki sifat antagonis yang mampu memarasit cendawan patogen tanaman dan menghambat pertumbuhan peekembangan cendawan lain. Penelitian ini bertujuan untuk mengetahui kemampuan formulasi suspensi pelet Trichoderma spp. dalam menghambat cendawan S. pogostemonis penyebab penyakit budok pada bibit nilam.

\section{METODE PENELITIAN}

Penelitian ini dilaksanakan di Laboratorium Penyakit Tumbuhan Jurusan Proteksi Tanaman, di NINO Park, dan di kebun percobaan ARC PUI PT Nilam, Universitas Syiah Kuala, Darussalam Banda Aceh. Waktu pelaksanaan dimulai pada bulan Januari sampai dengan Juni 2020.

\section{MATERI DAN METODE}

Penelitian ini menggunakan alat-alat yaitu pencetak pelet, laminar air flow, mikroskop, hand sprayer, pipet tetes, cangkul, saringan, pengayak tanah, alat tulis dan alat dokumentasi. Bahan yang digunakan dalam penelitian ini adalah stek 
nilam berasal dari Kecamatan Sampoiniet Kabupaten Aceh Jaya. Lima spesies isolat biakan murni cendawan antagonis T. virens, T. harzianum, T. artoviride, T. asperellum, T. hamatum, asal aceh yang diperoleh dari koleksi Laboratorium Ilmu Penyakit Tanaman Program Studi Proteksi Tanaman Fakultas Pertanian Universitas Syiah Kuala, bahan dasar pelet (dedak, ampas tahu, dan molase), potato dextrose agar (PDA) dan bahan-bahan lainnya.

\section{Metode Penelitian}

Rancangan Acak Lengkap (RAL) non faktorial dengan 6 perlakuan, setiap perlakuan terdiri dari 3 unit percobaan dan diulang sebanyak 4 kali sehingga diperoleh 72 unit percobaan.

\section{Prosedur Penelitian}

\section{Perbanyakan Cendawan Trichoderma spp.}

Perbanyakan isolat Trichoderma spp. dilakukan secara aseptik dalam laminar air flow. Trichoderma spp. diperbanyak pada media PDA yang ditempatkan pada cawan petri yang telah disterilkan.

\section{Pembuatan formulasi pelet Trichoderma spp.}

Pembuatan formulasi pelet merujuk pada penelitian Zikriah (2016) yang telah dimodifikasi. Bahan dasar pembuatan pelet adalah dedak ampas tahu (DAT). Ampas tahu dikeringkan lalu dihancurkan menggunakan blender dan diayak menjadi tepung ampas tahu. Kemudian adonan pelet dibuat dengan cara mencampurkan tepung ampas tahu sebanyak $10,5 \mathrm{~g}$, dedak $31 \mathrm{~g}$, molase $15 \mathrm{ml}$ dan aquades $42 \mathrm{ml}$ lalu diaduk hingga homogen dan dibungkus dengan plastik tahan panas kemudian disterilkan dalam autoclave dengan suhu $121^{\circ} \mathrm{C}$ selama 30 menit. Trichoderma spp. diinkubasi selama tujuh hari pada media PDA. kemudian dibuat suspensi $2 \mathrm{ml}$ lalu dimasukkan ke dalam adonan yang sudah diterilkan, diaduk agar cendawan merata pada adonan dan dibiarkan hingga terlihat tumbuh hifa cendawan.

\section{Persiapan Inokulasi Cendawan Patogen S. pogostemonis}

Sebelum inokulasi dilakukan terlebih dahulu di isolasi tanaman yang terserang S. pogostemonis yang diperoleh dari pembibitan Nilam NINO Park lalu dikumpulkan dan cuci bersih sebanyak 100 gr dipotong-potong kemudian dihaluskan dengan menggunakan blender dan ditambahkan aquadest 1 liter lalu disaring hingga menjadi suspensi (Idris dan Nasrun, 2009).

\section{HASIL DAN PEMBAHASAN}

\section{Masa Inkubasi (hari)}

Berdasarkan hasil sidik ragam menunjukkan bahwa formulasi suspensi pelet Trichoderma spp. tidak berpengaruh terhadap masa inkubasi yang disebabkan oleh patogen Synchitrium Pogostemonis pada bibit nilam. Rata-rata masa inkubasi patogen sejak inokulasi S. Pogostemonis dapat dilihat pada Tabel 2.

Berdasarkan data Tabel 2 pada pengamatan masa inkubasi menunjukkan perbedaan lamanya waktu yang dibutuhkan untuk menimbulkan gejala pertama, masa inkubasi tercepat dijumpai pada perlakuan T0 (kontrol). Hasil dari penelitian ini menunjukkan bahwa perlakuan suspensi pelet T2 (T. harzianum) mampu menunda masa inkubasi atau memperpanjang masa inkubasi dari patogen $S$. 
pogostemonis, Hal ini sejalan dengan penelitian Tronsmo (1996) bahwa cendawan. T. harzianum dapat menghasilkan enzim $\beta$ (1-3) glukanase, kitinase, dan enzim lisis yang merupakan mekanisme persaingan sehingga mampu mendegradasi dan menghidrolisis dinding sel miselium cendawan patogen.

Tabel 1. Rata-rata masa inkubasi (hari) sejak inokulasi S. pogostemonis

\begin{tabular}{cc}
\hline Perlakuan & Masa Inkubasi (hari) \\
\hline T0 (Kontrol) & 4,75 \\
T1 $($ T.virens $)$ & 5,00 \\
T2 $($ T. harzianum) & Tidak bergejala \\
T3 $($ T. artroviride $)$ & 5,00 \\
T4 $(T$. asperellum $)$ & 5,50 \\
T5 (T.hamatum) & 6,00 \\
\hline
\end{tabular}

Berbeda dengan perlakuan suspensi pelet $\mathrm{T} 1$ ( $T$. virens), T3 ( $T$. artroviride), T4 ( $T$. asperellum), dan T5 ( $T$. hamatum) memberikan pengaruh yang lebih baik dibandingkan dengan kontrol. Trichoderma sebagai agens hayati telah banyak diterapkan untuk mengendalikan berbagai patogen. Alfizar et al. (2013) menyatakan bahwa, Trichoderma spp. selama tujuh hari masa inkubasi dengan persentase penghambatan patogen Fusarium dan S. roflsii yaitu 53,9\% dan $35,5 \%$ sedangkan pada masa inkubasi selama tujuh hari persentase penghambatan patogen $C$. capsici secara in vitro yaitu sebesar 68,2\%. Selanjutnya Sriwati et al. (2015) menyatakan bahwa Trichoderma spp. dapat menghambat perkembangan patogen dengan cara kompetisi dan antibiotis. Trichoderma spp. dapat digunakan sebagai agen biocontrol yaitu dapat mengendalikan penyakit pada tanaman.

\section{Tinggi Tanaman $(\mathbf{c m})$}

Hasil analisis ragam menunjukkan formulasi suspensi pelet Trichoderma spp. tidak berpengaruh terhadap tinggi tanaman pada 1, 14, 28, HST namun berpengaruh tinggi tanaman nilam pada pengamatan 42 HST. Rata-rata tinggi tanaman nilam pada perlakuan formulasi suspensi pelet Trichoderma spp. dapat dilihat Tabel 3.

Hasil penelitian menunjukkan bahwa perlakuan suspensi pelet tidak berpengaruh nyata terhadap tinggi tanaman pada pengamatan 1, 14, dan 28 HST, tetapi berpengaruh nyata terhadap tinggi tanaman pada pengamatan $42 \mathrm{HST}$. Pada pengamatan 42 HST terjadi perbedaan dimana perlakuan T0 (kontrol) berbeda nyata dengan perlakuan yang lain yaitu perlakuan formulasi suspensi pelet T1 ( $T$. virens), T2 (T. harzianum), T3 (T. artroviride), T4 (T. asperellum), dan T5 (T. hamatum). Hal ini diduga karena tidak adanya hormon pemacu pertumbuhan dan tidak adanya mekanisme antagonis untuk menghambat perkembangan patogen yang didapatkan dari agens antagonis seperti Trichoderma spp., sedangkan pada perlakuan formulasi suspensi pelet T1 (T. virens), T3 (T. artroviride), T4 (T. asperellum), dan T5 (T. hamatum) memberikan hasil yang baik terhadap pertambahan tinggi tanaman pada setiap waktu pengamatan, namun pada perlakuan suspensi pelet T2 (T. harzianum) menghasilkan tinggi tanaman yang terbaik, diduga karena $T$. harzianum memiliki kemampuan sebagai plant growth stimulator yang dapat merangsang pertumbuhan tanaman. 
Tabel 2. Rata-Rata Tinggi Tanaman Nilam pada Perlakuan Formulasi Suspensi Pelet Trichoderma spp.

\begin{tabular}{ccccc}
\hline Perlakuan & \multicolumn{4}{c}{ Tinggi Tanaman $(\mathrm{cm})$} \\
\hline & 1 HST & 14 HST & $28 \mathrm{HST}$ & $42 \mathrm{HST}$ \\
\hline T0 & 21,5 & 21,9 & 22,2 & $23,7 \mathrm{a}$ \\
T1 & 21,2 & 24,0 & 24,5 & $26,6 \mathrm{bc}$ \\
T2 & 20,7 & 24,0 & 26,3 & $27,5 \mathrm{c}$ \\
T3 & 21,9 & 23,6 & 24,3 & $25,2 \mathrm{ab}$ \\
T4 & 20,3 & 21,7 & 22,4 & $26,9 \mathrm{bc}$ \\
T5 & 23,5 & 23,9 & 24,1 & $26,0 \mathrm{bc}$ \\
\hline BNT & - & - & - & 2,27
\end{tabular}

Keterangan : Angka-angka yang diikuti huruf yang sama pada kolom yang sama tidak berbeda nyata berdasarkan uji BNT pada taraf $5 \%$.

Gallavotti (2013) yang menyatakan bahwa hormon yang dikeluarkan oleh $T$. harzianum seperti hormon auksin berupa IAA yang berperan penting dalam pertumbuhan tanaman, seperti pertumbuhan akar dan batang tanaman yang menghasilkan perbedaan tinggi tanaman.

\section{Jumlah Daun (helai)}

Hasil analisis ragam menunjukkan formulasi suspensi pelet Trichoderma spp. tidak berpengaruh terhadap jumlah daun pada 1, 14, 28, HST dan berpengaruh sangat nyata terhadap jumlah daun tanaman nilam pada pengamatan 42 HST yaitu pada akhir penelitian.

Tabel 3. Rata-rata jumlah daun akibat formulasi suspensi pelet Trichoderma spp. pada pengamatan $1,14,28$, dan 42 HST

\begin{tabular}{ccccc}
\hline Perlakuan & \multicolumn{4}{c}{ Jumlah Daun } \\
\hline & 1 HST & 14 HST & 28 HST & $42 \mathrm{HST}$ \\
\hline T0 & 16,8 & 22,9 & 24,2 & $25,8 \mathrm{a}$ \\
T1 & 17,8 & 25,4 & 28,9 & $33,1 \mathrm{~b}$ \\
T2 & 21,4 & 28,3 & 33,0 & $41,5 \mathrm{c}$ \\
T3 & 17,3 & 22,8 & 27,7 & $34,5 \mathrm{~b}$ \\
T4 & 17,8 & 25,1 & 28,1 & $33,4 \mathrm{~b}$ \\
T5 & 20,5 & 25,0 & 27,0 & $32,2 \mathrm{~b}$ \\
\hline BNT & - & - & - & 6,19
\end{tabular}

Keterangan : Angka-angka yang diikuti huruf yang sama pada kolom yang sama tidak berbeda nyata berdasarkan uji BNT pada taraf $5 \%$. 
Tabel 4 menunjukkan bahwa jumlah daun tanaman nilam tertinggi pada umur 42 HST dijumpai pada perlakuan formulasi pelet suspensi pelet Trichoderma spp. berpengaruh nyata dibanding perlakuan kontrol. Hal ini diduga bahwa Trichoderma spp. berfungsi untuk memecah bahan-bahan organik seperti $\mathrm{N}$ yang terdapat dalam senyawa komplek, nitrogen berperan dalam pembentukan klorofil dimana nitrogen dimanfaatkan tanaman untuk merangsang pertumbuhan dan menjadikan daun berwarna hijau (Mariana, 2013).

Pada semua perlakuan yang diaplikasikan formulasi suspensi pelet Trichoderma spp. memberikan pengaruh terhadap meningkatmya jumlah daun, sedangkan pada perlakuan kontrol yang tidak diaplikasikan pelet Trichoderma spp. hanya diinokulasikan patogen $S$. pogostemonis menunjukkan jumlah daun yang terendah. Perlakuan yang menunjukkan jumlah daun tertinggi adalah T2 (T. harzianum). Dharmawan et al. (2014) menyatakan bahwa pemberian $T$. harzianum mampu menyediakan unsur hara yang lebih tinggi dalam mencukupi bahan untuk fotosintesis dengan memproduksi indole acetic acid (IAA) sehingga mampu meningkatkan jumlah akar dan jumlah daun serta meningkatkan pertumbuhan dan pembentukan sel seperti daun lebih tinggi. Secara umum diyakini bahwa keberadaan agens hayati dapat mempengaruhi peningkatan pertumbuhan tanaman menjadi lebih optimal dan mampu menekan perkembangan penyakit.

\section{Jumlah Tunas}

Berdasarkan dari analisis ragam jumlah tunas pada tanaman nilam tidak berpengaruh terhadap jumlah tunas pada 1, 14 HST, namun berpengaruh nyata pada pengamatan 28 HST dan 42 HST. Data ditampilkan sebagai berikut:

Tabel 4. Rata-rata jumlah tunas akibat formulasi suspensi pelet Trichoderma spp. pada $1,14,28$, dan 42 HST.

\begin{tabular}{ccccc}
\hline Perlakuan & \multicolumn{4}{c}{ Jumlah Tunas } \\
\hline T0 & 1 HST & 14 HST & 28 HST & 42 HST \\
T1 & 2,50 & 2,57 & $3,00 \mathrm{a}$ & $3,42 \mathrm{a}$ \\
T2 & 3,09 & 3,33 & $3.92 \mathrm{~b}$ & $4,67 \mathrm{~b}$ \\
T3 & 2,67 & 2,92 & $5,08 \mathrm{c}$ & $6,75 \mathrm{c}$ \\
T4 & 2,67 & 3,00 & $3,75 \mathrm{~b}$ & $4,58 \mathrm{~b}$ \\
T5 & 3,09 & 3,33 & $3,83 \mathrm{~b}$ & $4,84 \mathrm{~b}$ \\
\hline BNT & - & - & $0,63 \mathrm{~b}$ & $5,00 \mathrm{~b}$ \\
\hline
\end{tabular}

Keterangan : Angka-angka yang diikuti huruf yang sama pada kolom yang sama tidak berbeda nyata berdasarkan uji BNT pada taraf $5 \%$.

Tabel 5 menunjukkan bahwa jumlah tunas tanaman nilam akibat perlakuan T0 (Kontrol) berbeda nyata dengan semua perlakuan namun pada perlakuan formulasi suspensi pelet $\mathrm{T} 2$ ( $T$. harzianum) berbeda nyata dengan semua perlakuan lainnya. Sedangkan pada perlakuan kontrol yang tidak diaplikasi pelet 
Trichoderma spp. hanya diinokulasikan patogen S. Pogostemonis menunjukkan jumlah tunas yang rendah, hal ini disebabkan pertumbuhan tanaman terhambat sehingga menurunkan ketahanan tanaman terhadap infeksi patogen, yang menyebabkan tanaman mudah terserang penyakit.

Pada semua perlakuan formulasi suspensi pelet Trichoderma spp. yaitu T1 (T. virens), T2 (T. harzianum) T3 (T. artroviride), T4 (T. asperellum), dan T5 (T. hamatum). yang diaplikasikan pada tanaman nilam menghasilkan jumlah tunas yang berbeda-beda dan juga efektif dalam meningkatkan jumlah tunas tanaman nilam dengan menekan perkembangan S. Pogostemonis. Perlakuan yang menunjukkan hasil jumlah tunas tanaman tertinggi ialah pada formulasi suspensi pelet T2 (T. harzianum) yang memiliki jumlah tunas paling banyak. Triyatno (2005) menyatakan bahwa T. harzianum memproduksi hormon asam giberelin, asam indol asetat (IAA) dan benzyl amino purin (BAP) dalam jumlah yang besar sehingga mampu merangsang pertumbuhan tanaman lebih optimum.

\subsection{Intesitas Serangan Penyakit}

Berdasarkan hasil sidik ragam menunjukkan bahwa perlakuan formulasi suspensi pelet Trichoderma spp. memberikan pengaruh sangat nyata terhadap intensitas serangan patogen $S$. pogostemonis pada tanaman nilam. Rata-rata intensitas serangan patogen $S$. pogostemonis pada tanaman nilam akibat perlakuan Trichoderma spp. pada pengamatan 42 HST dapat dilihat pada Tabel 6.

Tabel 5. Rata-rata intensitas serangan patogen S. pogostemonis pada tanaman nilam akibat perlakuan Trichoderma spp. pada pengamatan 42 HST.

\begin{tabular}{cc}
\hline Perlakuan & Rata-rata \\
\hline T0 (Kontrol) & 39,0 \\
T1 (T.virens) & $(38,6)_{\mathrm{c}}$ \\
& 14,6 \\
T2 (T. harzianum) & $(22,4) \mathrm{b}$ \\
& 0,00 \\
T3 $($ T. artroviride $)$ & $(0,58) \mathrm{a}$ \\
& 17,4 \\
T4 $($ T. asperellum $)$ & $(24,7) \mathrm{b}$ \\
& 14,7 \\
T5 (T.hamatum) & $(22,5) \mathrm{b}$ \\
& 15,8 \\
BNT & $(23,4) \mathrm{b}$ \\
\hline
\end{tabular}

Keterangan : Angka-angka yang diikuti huruf yang sama pada kolom yang sama tidak berbeda nyata berdasarkan uji BNT pada taraf 5\%. Angka yang berada di dalam () merupakan angka hasil transformasi $\operatorname{arc} \sin \sqrt{ } \mathrm{x}$.

Pada Tabel 6 terlihat bahwa intesitas serangan patogen pada perlakuan T0 (kontrol) berbeda sangat nyata dengan perlakuan formulasi suspensi pelet Trichoderma spp. T1 (T. virens), T2 (T. harzianum), T3 (T. artroviride), T4 (T.asperellum), dan T5 (T. hamatum). Intesitas serangan penyakit tertinggi ditunjukkan oleh perlakuan T0 (kontrol) yaitu 39,0\% diikuti oleh perlakuan T3 (T. artroviride), T5 (T. hamatum) $\mathrm{T} 4$ ( $T$. asperellum), dan $\mathrm{T} 1$ ( $T$. virens) 
menunjukkan intesitas serangan yang lebih rendah dibanding dengan perlakuan kontrol. Sedangkan pada intesitas serangan terendah diperoleh pada perlakuan T2 (T. harzianum) yaitu 0\% sampai akhir pengamatan tidak menunjukkan gejala. Hal tersebut menunjukkan bahwa kemampuan $T$. harzianum dalam meningkatkan induksi ketahanan terhadap tanaman. Induksi ketahanan merupakan kondisi fisiologis yang mengatur sistem ketahanan menjadi aktif dengan menstimulasi mekanisme resistensi yang dimiliki oleh inang. Amaria dan Wardiana (2014) menyatakan bahwa salah satu fungsi Trichoderma dapat meningkatkan ketahanan tanaman melalui mekanisme ISR (Induced Systemic Resistence) sehingga tanaman mengaktifkan sistem ketahanan dengan menstimulasi mekanisme resistensi yang dimilikinya. Hal tersebut jelas menunjukkan bahwa agens hayati yang digunakan memiliki potensi melindungi tanaman terhadap infeksi patogen.

\subsection{Berat Basah Tanaman Nilam (g)}

Berdasarkan hasil analisis ragam bahwa perlakuan formulasi suspensi pelet Trichoderma spp. yaitu tidak berpengaruh terhadap berat basah. Berat basah tanaman nilam akibat perlakuan formulasi suspensi pelet beberapa spesies Trichoderma sp. dapat dilihat pada Tabel 7.

Tabel 6. Berat BasahTanaman Nilam pada Perlakuan Formulasi Suspensi Pelet Trichoderma spp.

\begin{tabular}{cc}
\hline Perlakuan & Berat Basah $(\mathrm{g})$ \\
\hline T0 & 10,2 \\
T1 & 18,2 \\
T2 & 29,4 \\
T3 & 24,2 \\
T4 & 21,3 \\
T5 & 20,1 \\
\hline
\end{tabular}

Tabel 7 menunjukkan bahwa semua perlakuan yaitu T0 (kontrol), T1 ( $T$. virens), T2 (T.harzianum), T3 (T. artroviride), T4 (T.asperellum), dan T5 ( $T$. hamatum) tidak berpengaruh terhadap berat basah tanaman. Perlakuan tertinggi adalah pada perlakuan T2 (T.harzianum) yaitu 29,41 g, diikuti pada perlakuan T3 (T. artroviride), T4 (T.asperellum), dan T5 (T. hamatum) dan ( $T$. virens) memberikan pengaruh yang lebih baik dan hasil terendah diperoleh dengan berat basah tanaman nilam sebesar 10,23 g yaitu pada T0 (kontrol). Hal ini disebabkan pada perlakuan T0 (kontrol) tanaman sudah terinfeksi oleh patogen $S$. pogostemonis yang dapat menyerang daun, tangkai daun dan batang tanaman nilam, sehingga tanaman nilam tidak dapat tumbuh dengan optimal. Aplikasi suspensi pelet Trichoderma spp. menunjukkan bahwa tanaman nilam mampu merespon dengan baik pada proses pertumbuhan tanam nilam. Hal ini sejalan dengan pendapat Cornejo et al. (2009) bahwa, Tichoderma spp. mampu mempengaruhi pertambahan panjang batang, pertumbuhan akar lateral, 
memperbanyak tunas serta meningkatkan biomasa dari tunas pada tanaman karena menghasilkan hormon auksin diantaranya adalah IAA.

\subsection{Berat Kering Tanaman Nilam (g)}

Berdasarkan hasil analisis ragam bahwa perlakuan formulasi suspensi pelet Trichoderma spp. tidak berpengaruh terhadap berat kering tanaman nilam. Hasil pengamatan berat kering tanaman nilam dapat dilihat pada Tabel 8 .

Tabel 7. Berat Kering Tanaman Nilam pada Perlakuan Formulasi Suspensi Pelet Trichoderma spp.

\begin{tabular}{cc}
\hline Perlakuan & Berat Kering $(\mathrm{g})$ \\
\hline T0 & 5,44 \\
T1 & 7,48 \\
T2 & 10,4 \\
T3 & 8,18 \\
T4 & 8,04 \\
T5 & 7,99 \\
\hline BNT $_{0,05}$ & \\
\hline
\end{tabular}

Tabel diatas menunjukkan bahwa secara statistik tidak berbeda nyata antar perlakuan yang dicobakan namun berdasarkan data berat basah yang diukur diketahui bahwa hasil berat kering tanaman nilam tertinggi pada perlakuan T2 (T.harzianum) dengan hasil $10,37 \mathrm{~g}$ dan hasil terendah yaitu $5.44 \mathrm{~g}$ pada perlakuan T0 (kontrol). Hal ini menunjukkan bahwa pemberian Trichoderma spp. pada tanaman nilam mempunyai pertumbuhan yang lebih baik dibandingkan dengan kontrol. Trichoderma spp. merupakan cendawan yang bersifat antagonis terhadap cendawan patogen dan juga penggunaan cendawan ini tidak menimbulkan pencemaran lingkungan dan dapat meningkatkan keseimbangan ekosistem. Salah satu dari spesies Trichoderma spp. yaitu T.harzianum (T2) dalam hasil penelitian menunjukkan berat kering tanaman nilam tertinggi hal ini diduga bahwa T.harzianum mampu menghasilkan kedua jenis senyawa trichorzins dan harzianins berupa senyawa metabolit sekunder yang diduga menghambat pertumbuhan cendawan patogen karena bersifat antibiosis dan menghasilkan senyawa racun (mytoxin) (Christita et al., 2014).

\section{KESIMPULAN}

1. Formulasi suspensi pelet Trichoderma spp. mampu menghambat cendawan Synchitrium pogostemonis penyebab penyakit budok pada bibit nilam.

2. Formulasi suspensi pelet Trichoderma harzianum mampu meningkat pertumbuhan tanaman nilam terhadap parameter tinggi tanaman, jumlah daun dan jumlah tunas pada 42 HST. 


\section{DAFTAR PUSTAKA}

Alfizar, M dan S. Fitri 2013. Kemampuan antagonis Trichoderma sp. terhadap beberapa jamur patogen in vitro. J Floratek. Vol. 8 (1): 45-51.

Amaria, W dan E. Wardiana. 2014. Pengaruh waktu aplikasi dan jenis Trichoderma terhadap penyakit amur akar putih pada bibit tanaman karet. J. TIDP. Vol. 1(1): 79-86.

Christita, M., M.S. Widyastuti., dan H. Djoyobisono. 2014. Pengendalian hayati penyebab penyakit rebah semai Fusarium subglutinans dengan Trichoderma harzianum. J Pemuliaan Tanaman Hutan. Vol.8 (1): 43-55.

Cornejo, C. H. A., L. Marcias., C. Rodrigues., C. Penagos and J.L. Bucio. 2009. Trichoderma virens a plant benefecial fungus, enchances boimass production and promotes lateral root growth trough an auxin dependent mechanism in aradiopsis. J. Plant Physiol. 149: 1579-1592.

Dharmawan, M. L., Yunasfi, dan M. Basyuni. 2014. Pemanfaatan fungi Aspergillus flavus, Aspergillus terreus dan Trichoderma harzianum untuk meningkatkan pertumbuhan bibit Bruguiera gymnorrhiza. Skripsi. Program Studi Kehutanan Fakultas Kehutanan, Universitas Sumatera Utara, Medan.

Gallavotti, A. 2013. The Role of Auxin in Shaping Ahoot Architecture. J. of Experimental Botany.64.9.2593-2608. http://doi.org/10.1093/jxb/ert141.

Idris, H. dan Nasrun. 2009. Pengaruh cara inokulasi Synchytrium pogostemonis terhadap gejala budok dan pertumbuhan nilam. Bul. Littro. 20 : 157-166.

Mariana, 2013. Analisa Pemberian Cendawan Trichoderma sp. terhadap Pertumbuhan Kedelai. Karya Tulis Ilmiah. Balai Pelatihan Pertanian Jambi.

Ningsih, T., Wijaya., S. Wahyuasih. 2015. Pengaruh Jumlah Ruas Stek terhadap Pertumbuhan Bibit Nilam (Pogostemon Cablin Benth.). Tesis. Program Studi Agronomi, Pascasarjana Unswagati.

Panjaitan, S. dan Y. Nuraeni. 2014. Teknik pengembangan nilam (Pogostemon cablin Benth.) Di Kalimatan Selatan. Balai Penelitian Kehutanan Banjarbaru. Galam Vol. 7 (1): 31-42.

Soekarno, B., S. Surono., S. Susanti. 2014. Formula pelet berbahan aktif Trichoderma sp. dan aplikasinya terhadap penyakit rebahk kecambah pada tanaman mentimun. Jurnal Fitopatologi Indonesia. Vol.10:153159. https://doi.org/10.14692/jfi.10.5.153.

Sriwati, R. R. L. Melnick., M. Rizky., D. Mary., Stream., J. G. Samuels., B.A. Bailey. 2015. Trichoderma from Aceh Sumatra reduce Phytophthora lesions on pods and cacao seedlings. J. Biological control. 89: 33-41.

Sukamto, N. Listiana., R. Indrayanti., D. Wahyuno. 2019. Isolation and characterization of potential isolates of rhizosphere bacteria to control budok disease in Patchouli plant. Buletin Penelitian Tanaman Rempah dan Obat. Vol. 30 (1): 35-46.

Suswanto, I. 2014. Kajian formulasi mutan Trichoderma sebagai kandidat agens pengendali hayati hawar beludru Septobasidium pada lada. Program Studi Agroteknologi Fakultas Pertanian Universitas Tanjungpura. Vol 4 (2): 22-29. 
Triyatno, B.Y. 2005. Potensi beberapa agensia pengendali terhadap penyakit busuk rimpang jahe. Skripsi. Fakultas Pertanian Universitas Jenderal Soedirman. Purwokerto.

Tronsmo, A. 1996. Trichodrema harzianum in Biological Control of Fungal Diaseses. Pp.212-221. In: R. Hall (Ed.), Principles and Practise of Managing Soilborne Plant Pathogens.APS Press, St. Paul.Minnesota.

Yuliyanti, T., Y.S. Hartati., R. Indrayanti. 2017. Uji Ketahanan Nilam terhadap Synchytrium pogostemonis Penyebab Penyakit Budok dan Potensi Pengendaliannya dengan Pestisida Nabati. Program Studi Biologi FMIPA Universitas Negeri Jakarta. BIOMA 13 (2): 90-99.

Zikriah, 2016. Potensi Daun katuk dan lamtoro sebagai nutrisi kamur Trichoderma sp. Pada pelet media tumbuh dalam menekan pertumbuhan patogen Tular tanah. Skripsi. Unsyiah. Banda Aceh. 